\title{
Analysis of the Effect about Zero-tariff of China-ASEAN Free Trade
}

\author{
Yan LIU ${ }^{1, a, *}$, Peng ZHANG ${ }^{2, b}$ \\ ${ }^{1}$ Department of accounting, Jiangcheng College, China University of Geosciences \\ ${ }^{2}$ Department of electronics, Wuhan Mechanical College, China \\ aYuki021@163.com, bbigbird616@sohu.com \\ ${ }^{*}$ Corresponding author
}

Keywords: China-ASEAN FTA, Zero-tariff, Theory effect, Demonstration effect

\begin{abstract}
Zero-tariff is the ultimate goal of regional trade liberalization. China-ASEAN FTA agreement on trade is the first real sign of China on regional free trade agreement. The main purpose of this protocol is to enhance regional competitive advantage, promote regional trade, and optimize the allocation of resources. Through reducing the tariff and non-tariff barriers between participating nations, create greater economic efficiency, productivity and competitiveness. This paper aims to analyze the theory of effect and demonstration effect in CAFTA zero tariff. And then analyze trading benefits on importing and exporting which coming from zero-tariff in CAFTA based on the theory of empirical.
\end{abstract}

\section{Part1.Zero tariff related overview in CAFTA}

\section{ASEAN Free Trade Area, AFTA}

1992 January held in Singapore from Indonesia, Malaysia and other ASEAN countries in the ASEAN trade ministers meeting, the meeting signed the "establishment of ASEAN Free Trade Area" (ASEAN Free Trade Area, referred to as AFTA) protocol. The establishment of the main purpose of the ASEAN free trade area lies in the enhancement of ASEAN as a single unit of production competitive advantage; through the reduction of tariff and non-tariff barriers among Member States, looking forward to create greater economic efficiency, productivity and competitiveness; to strengthen the ASEAN regional integration and trade and investment promotion alliance zone.

\section{China-ASEAN Free Trade Area, CAFTA}

In January 1, 2010 China ASEAN Free Trade Area officially completed. After the completion of CAFTA, Chinese and ASEAN about 7000 products, enjoy zero tariff treatment, realize the liberalization of trade in goods. CAFTA regional economic pattern of free trade, common external tariff barriers.

\section{Zero-tariff}

Zero tariff is the import and export commodity after the customs territory of a state, the Department set up by the government not to the import and export tariffs. Regional preferential certificate of origin of import and export goods with the entry-exit inspection and quarantine agencies issued, in the importing country can enjoy the tariff reduction, the reduction rate as low as $5 \%$ to $100 \%$, i.e., zero tariff. Zero tariff mechanism of CAFTA protocol are imports originating in the ASEAN to implement than the MFN tariff rates more preferential tariff rates 


\section{The implementation process of China-ASEAN FTA zero tariff}

The first stage (2002 to 2010): start and slashed tariff stage. In 2002 November, China and ASEAN signed with the China ASEAN Free Trade Area as the main content of the "China ASEAN comprehensive economic cooperation framework agreement", agreed in January 1, 2010, China on trade tariffs on $93 \%$ products ASEAN to zero.

The second stage (2011 to 2015): fully completed stage of free trade area, namely, Vietnam, Laos, Kampuchea, ASEAN countries and Burma Chinese trade most of products are also achieved zero tariffs, at the same time, both sides realize more deeply and widely opening the service trade market and investment market.

The third stage (after 2016): free trade area consolidation stage.

\section{Part2.The theoretical effects of CAFTA zero-tariff}

\section{The short-run effect of CAFTA zero-tariff}

CAFTA zero tariff era, which can produce the most direct of the effect on the economy in the short term, especially producing the growth of bilateral trade between China and ASEAN. Since the implementation of zero-tariff, so many domestic products manufacturers export products to ASEAN countries and then import the required products, the bilateral trade grow rapidly.

\section{The long-run effect of CAFTA zero-tariff}

\section{The benefit scope expanded from zero-tariff region}

China Yunnan province and Guangxi province is bordered by the ASEAN Burma, Laos, Vietnam, border trade prevailing. Therefore, the CAFTA zero tariff effect first arrived in Yunnan province and Guangxi Province, total value of trade greatly increased between the two provinces and ASEAN countries. With the start-up of Chinese and ASEAN Free Trade Area and the implementation of zero tariff, total trade in Yunnan and Guangxi and ASEAN increased rapidly, compared with the large surplus. While the CAFTA zero tariff long-term implementation, will not only make the ASEAN countries bordering Guangxi, Yunnan two provinces benefit, will also drive and ASEAN adjacent to the southwest area development. And then effect will expand in this area, and eventually extended to the country, to promote the China economic take-off.

\section{The Influence of zero tariff coordinating multiples development}

Consumers, enterprises, government, three party beneficiary

With the implementation of zero-tariff, many products are pouring into the China ASEAN market. And because of the influence of the zero-tariff, reducing the additional cost, so the product prices become much lower than in the past. China ASEAN zero-tariff directly benefit consumers. The implementation of zero-tariff, reduce corporate tax and other production costs, promote enterprise scale production, and can promote mutual investment among regions, especially in the foreign enterprise under the pressure, let "producing" enterprises more competitive. Zero-tariff can reduce government revenue in the short term. However, the political effects of zero tariff brings to Chinese government is long-term, and the political effect in the future will translate into more economic benefit.

\section{The structure of agricultural products achieve complementary advantages}

Since the zero-tariff, ASEAN countries Chinese tropical fruit into the market, but also open up a bigger market for all kinds of fruit Chinese. ASEAN countries are located in tropical and subtropical area, which produce and export tropical and subtropical agricultural products. And in 
China, except southeast provinces have similar natural conditions of ASEAN, the majority of provinces located in the temperate, so Chinese and ASEAN countries are highly complementary in the agricultural products trade. Our country has many varieties in temperate fruit and vegetable products, compared with the ASEAN countries, such as cheap price, comparative advantage. At the same time, as the ASEAN countries in the advantage in tropical fruits, grains and other land intensive agricultural production, which can reduce domestic resource cost of China's relatively high agricultural products (such as cereals, sugar and other crops) acreage and output in the total sown area and total output in proportion, while increasing the temperate Zone crop of our country planting area and export production, achieve complementary advantages, promote the diversification of trade between the two parties, and further optimize the allocation of resources, promote the optimization of agricultural structure in china.

\section{Promoting the coordinated development of economy, culture}

The implementation of zero-tariff is conducive to economic growth. The most direct effect of CAFTA zero-tariff is the bilateral trade volume growing. Especially as the China and ASEAN have the products are highly complementary, with the coming of zero tariff era, Chinese and ASEAN trade complementary development potential will become more prominent, the complementary trade greatly enrich the bilateral market. In the zero-tariff, raw material prices between China and ASEAN products, greatly reduced, improving the attractiveness of the investment.

The implementation of zero-tariff is beneficial to both sides for cultural exchanges. In second Century BC, the Silk Road, the two close personnel exchanges, they have something in common in a wide range of lifestyle, culture and etc., can be described as "cultural similarities". China and ASEAN culture fusion laid the foundation. And the implementation of CAFTA zero-tariff, in the economic development, the countries need to understand each other's habits and customs, cultural traditions, and zero tariff effect is the catalyst for this kind of cultural fusion.

\section{Part3. The Demonstration effect of CAFTA zero-tariff}

\section{The analysis of rules of origin CAFTA zero-tariff effect}

\section{The effects of regional value content standard}

Regional value content standard is the basic standard of the FTA in the application. Suitable for CAFTA standard is, native to China-ASEAN Free Trade Area of the product components accounted for the proportion of the total value of not less than 40\%; the total value of native to the non free trade area of the materials, parts or products shall not exceed the production or obtain product FOB price $60 \%$, and ultimately the production process is completed in the Chinese-ASEAN FTA agreement.

For example: The FOB is $\$ 100$, which product Malaysia export to China. A part of the product use the raw materials from American (except the raw materials the materials without the use of originating in other countries). The CIF is $\$ 43$ since the materials America export to Malaysia, for the value of the materials for non FTA a product of FOB was $43 \%$, less than $60 \%$, so the product can be regarded as originating in Malaysia, can also enjoy the preferential tax rate of FTA.

The components in Chinese-ASEAN FTA can be accumulated. That is as long as the value of raw materials to a particular country or a product origin FTA but not limited to trade in more than $40 \%$ of the total value, can be regarded as Chinese-ASEAN FTA raw products.

The above, if the FOB is $\$ 100$ when Malaysia export a product to China, which including \$20 from Indonesia, raw materials, Thailand from the original materials of $\$ 20, \$ 10$ Malaysia local materials, although a products in Malaysia only $10 \%$ of the total value added, but native to China 
reached $\$ 50(20+20+10$ components), the total value of the ratio of $50 \%$, reached the FTA product components accounted for the proportion of the total value of not less than $40 \%$ of the standard, so a product can be regarded as the FTA of original products, can enjoy the preferential tax rate of FTA.

Table 1 Tax reduction mode in China - ASEAN countries with a rail normal products

\begin{tabular}{|c|c|c|c|c|}
\hline$X$ China - ASEAN FTA preferential rates & 2005 & 2007 & 2009 & 2010 \\
\hline $\mathrm{X}>20 \%$ & 20 & 12 & 5 & 0 \\
$15 \%<\mathrm{X}<20 \%$ & 15 & 8 & 5 & 0 \\
$10 \%<\mathrm{X}<15 \%$ & 10 & 8 & 5 & 0 \\
$5 \%<\mathrm{X}<10 \%$ & 5 & 5 & 0 & 0 \\
$\mathrm{X}<5 \%$ & ---- & 0 & 0 \\
\hline
\end{tabular}

The product which come from FTA, if the "one track protocol" trade in goods in normal product standards, according to the agreement rate calculation, from the beginning of 2010 tariffs to zero, then the import link only need to pay the corresponding import value-added tax and consumption tax, the tax is not words but pre.

\section{The Certificate effect of origin}

About $93 \%$ of the products in Chinese-ASEAN FTA can enjoy zero tariff treatment by preferential certificate of origin. Exporting enterprises apply for preferential certificate of origin from the inspection and quarantine departments, can get preferential tariff trade regional countries to give.

For example, the trade of electromechanical (auto parts) in CAFTA, the rate in 2005 is $5 \%$ to 20\%. But in January 1, 2010, the six old ASEAN member states including Thailand reduce to zero, according to the agreement will import tariffs on auto parts. Even if the vehicle as sensitive products tax list, still maintain $25 \%$ import tariff. The overall cost but reduce the cost of imports is no doubt parts will make cars to reduce, and one of the main producing area of ASEAN and auto parts.

\section{The analysis from transferring industry aspects of CAFTA zero-tariff}

As China join to WTO, China and whole world are going into a new level about offshore. Now, a new round of "offshore production" will also appear in the CAFTA agreement on trade effect. We use the name is "the transfer of industry". China also use ASEAN local artificial and energy may. Directly to reduce the total cost of production and investment in human capital and technology progress indirectly reduce the total cost of production, is a major factor in the decision Chinese undertake more foreign offshore outsourcing process.

Chinese manufacturing, especially in labor-intensive industries, is the foundation of industrial development in china in recent years. Transfer of global industry of cross-border, international transfer of industry to undertake business in China, especially in the southeast coastal areas of the processing industry in the brand building, capital operation, industry has accumulated a significant advantage. At the same time, the comparative advantage of labor cost, land resources and other aspects of are disappearing. Manufacturing enterprises are now facing the East is mainly labor cost pressures. China can be able to lower the cost, will be to the developed degree not high end of industry chain of the ASEAN countries, the transfer of labor intensive industry in these countries, to meet the industrial upgrading, the consumer market needs at the same time, to realize their own industrial upgrading, industrial structure adjustment in the international region. 
For example: America give Vietnam permanent most favored nation treatment, but never give Chinese GSP treatment. And for the most products which China export to American like textiles and clothing, tax high tariffs on more than $30 \%$ tariff level. American garments import tax different according to types of fabric, the import tariff rate from $15 \%$ to $36 \%$. At present, Chinese products in the low-end market share is higher, tariff structure products in significantly limit China value-added industrial semi-finished and manufactured goods higher exports to the United States, the tariff structure makes the China product at a competitive disadvantage in the America market. In the face of such international trade protection, Chinese can make use of the transfer of industry, will focus on China's high tariffs products transferred to Vietnam for a class to get more preferential trade treatment from the developed countries such as America ASEAN region, the origin of products become ASEAN countries use the rules of origin, export to these countries, to avoid international trade protection in a certain degree on the. The move, is not only the production cost savings, the domestic industrial structure adjustment and upgrading is to Chinese, actively respond to effectively reflect the international anti-dumping and other trade protection.

In the CAFTA zero tariff agreement, influence on economy and trade is decreasing year by year. ASEAN will become the raw material China largest import and export business, reduce raw material export and import link tax, security of raw materials and energy supply, reduce the domestic price of cost, avoid the negative affects trade barrier, in order to meet the stable development of enterprises import and export trade for long. Therefore, only by actively participating in the CAFTA zero tariff mechanism, to strengthen the competitive advantage, and create greater economic benefit, realizing the maximization of import and export trade interests.

\section{References}

[1] Ma Heran, Research on the economic benefit of a China ASEAN Free Trade Area, Chinese trade, 2013(15)

[2] Xie Debao, The impact on agricultural products in China-ASEAN zero-tariff area, Industry Review,2009(2)

[3] Luo Xing, China ASEAN countries between tax competition and coordination, Journal of Wuzhou University, 2007(01)

[4] Liu Jie, The significance and strategy of building China ASEAN Free Trade Area,, Journal of Shaoguan University, 2011(01)

[5] Chen Wanling ,China ASEAN Free Trade Area: the strategic conception of the ASEAN based on Economic Community blueprint, Southeast Asia,2013(01)

[6] Han Congyi, The influence of the ASEAN Free Trade Area of the bilateral trade China - -- Based on the theory of Customs Union. Modern commerce industry, 2010(15)

[7] Wang Hongxiao,Chinese - property of ASEAN Free Trade Area tax coordination, Tax research,2013(05) 